\title{
Disaggregating Corporate Freedom of Religion
}

\author{
Sune Lœgaard
}

Jean L. Cohen identifies the idea in recent American Supreme Court jurisprudence that freedom of religion should not simply be understood as an ordinary legal right within the framework of liberal constitutionalism but as an expression of deference by the state and its legal system to religion as a separate and independent jurisdiction with its own system of law over which religious groups are sovereign within their own spheres of competence. ${ }^{1}$ Cohen argues that this is a revisionary and controversial idea which threatens the liberal constitutional order. While Cohen focuses on a specifically American legal-constitutional issue, her discussion nevertheless raises more general issues concerning the understanding of freedom of religion which are also relevant outside of the US.

The idea identified and criticized by Cohen is often called 'church autonomy'. In this comment, I discuss the relationship between, on the one hand, ordinary rights of freedom of association and freedom of religion and, on the other hand, church autonomy, which I also refer to as 'corporate freedom of religion' in order to highlight the difference. While proponents of church autonomy have been criticized and have responded to some of the criticisms, less discussion has focused on what the positive justification for claims about church autonomy is. I investigate various arguments articulated or assumed to support church autonomy and argue that these arguments conflate different issues, elide important distinctions, and equivocate over crucial terms. There is accordingly a need for disaggregation of the concerns raised under the heading of church autonomy. This significantly weakens the apparent case for church autonomy and supports Cohen's criticism of the idea that freedom of religion should be seen as a matter of competing jurisdictions.

\section{Church autonomy}

The jurisdictional reading of freedom of religion identified by Cohen has been labelled 'church autonomy'. ' Since this is a label that has been carried over to European discussions, ${ }^{3}$ I will use it for present purposes. The basic idea is to dis-

1 Jean L. Cohen, 'Freedom of Religion Inc.: Whose Sovereignty?' Netherlands Journal of Legal Philosophy 44(3) (2015): 169-210.

2 Douglas Laycock, 'Church Autonomy Revisited', Georgetown Journal of Law and Public Policy 7 (2009): 253-78. The label originates in Douglas Laycock, 'Towards a General Theory of the Religion Clauses: The Case of Church Labor Relations and the Right to Church Autonomy', Columbia Law Review 81 (1981): 1373-417.

3 Lisbet Christoffersen, 'Church Autonomy in Nordic Law', in Law \& Religion in the 21st Century Nordic Perspectives, eds. Lisbet Christoffersen, Kjell Å Modéer and Svend Andersen (Copenhagen: DJØF Publishing, 2010), 563-92. 
tinguish between conscientious objection claims and church autonomy claims, where 'A conscientious objection claim says that for religious reasons, I cannot do what the government demands. ... A church autonomy claim is a claim to autonomous management of a religious organization's internal affairs'. ${ }^{4}$ So church autonomy denotes 'the freedom of the church to govern and order itself and the limits on the secular power to interfere with that governance'. ${ }^{5}$ The recent cases involving corporate freedom of religion that Cohen discusses extend this protection from decisions over internal religious dogma and appointment of ministers to exemptions from federal civil rights laws against certain types of discrimination in employment - in the Hosanna-Tabor case, the Supreme Court in practice extended church autonomy to cover any religious organization, in this case a school, and any job function in that organization whether or not the job function had a religious nature.

Since this case and cases similar to it are decided with reference to church autonomy, the question is what the justification is for thinking that religious organizations should have this kind of corporate protection and whether this justification is strong enough to support the extensive scope given to it by the Court.

\section{Church autonomy beyond freedom of association}

Church autonomy claims that freedom of religion must not only protect individual freedom of belief, conscience, and practice but also protect collective forms of religious practice and the organizational structures that religious communities erect as frameworks for these practices.

Here a complication arises, for these activities are also protected - as most proponents of church autonomy acknowledge - by the right to freedom of association. ${ }^{6}$ This complication is not only a question of there being additional legal measures protecting church autonomy, it rather obscures whether the actual protection afforded in particular cases comes from freedom of religion or from freedom of association. If the protection is provided by freedom of association, which is a general right not specific to religious organizations, then freedom of religion may not be needed to protect these kinds of activities.

This issue of redundancy comes down to the point whether a) freedom of religion really provides any protection of church autonomy not already provided by freedom of association, or b) whether it does - in which case it becomes necessary to specify what the additional protection afforded to religious organizations by freedom of religion beyond that afforded by freedom of association is, and to provide a justification for this additional protection. If corporate freedom of religion is not

$4 \quad$ Laycock, 'Church Autonomy Revisited', 254.

5 Richard W. Garnett, “The Freedom of the Church": (Towards) an Exposition, Translation, and Defense', Journal of Contemporary Legal Issues 21 (2013): 37.

6 E.g., Rex Ahdar and Ian Leigh, Religious Freedom in the Liberal State (Oxford: Oxford University Press, 2005), 326. 
redundant, then there is indeed something special about religious organizations, at least in the sense that they have legal protection other associations do not enjoy.

Church autonomy is commonly formulated with reference to the so-called 'internal affairs' of religious organizations, which secular laws or courts should not interfere with. But note that ordinary freedom of association also implies that other, non-religious organizations can have internal affairs in a similar general sense; if freedom of association protects the setting up of associations with bylaws, and these not only concern public issues about ownership of property, who can act as legal representative of the organization, etc. but also the subject matter around which the organization is formed, there is no reason not to think that, say, chess clubs, or political parties should not have internal affairs as well. Just as the internal affairs of religious organizations are reasonably held to include issues about religious dogma, rituals, and organizational structure, so would it be plausible to claim that, say, chess clubs have internal affairs regarding the rules of chess, the proper way of conducting chess tournaments, and the criteria for appointing chess champions, which it is not the business of governments or civil law to rule on or interfere with.

Church autonomy is commonly and most importantly thought to go beyond ordinary freedom of association in two respects:

a The internal affairs of religious organizations are thought to be areas which secular courts cannot adjudicate on, since this would imply that secular courts can judge in matters concerning religious disputes, and

b religious organizations are considered as being beyond the scope of - or being exempted from - certain laws, especially laws concerning discrimination in employment, since the religious nature of the organizations is thought to imply that the selection of employees on religious grounds is a relevant concern in relation to certain job functions.

The rationale of these special protections has to do with the religious nature of the organizations. In the first case, their religious nature is thought to imply that secular courts are incompetent in adjudicating in internal disagreements, simply because secular courts are not knowledgeable about or authoritative over religious doctrine, and because adjudicating on religious issues would compromise the secular nature of courts. So, this special protection is in a sense just as much a protection of the secular courts as of the religious organizations.

The rationale for the protection in the second case has to do with the fact that ordinary laws against discrimination operate with standard lists of protected features, differential treatment on the basis of which is illegal. Religion figures on most such lists of protected features, simply because religion is often a ground of discrimination. But in precisely the case of at least some religiously defined job functions in religious organizations, religion arguably is a relevant feature, and accordingly differential treatment on the basis of this feature is not unjust. So 
one way to understand the second case in which church autonomy is thought to be special is that it is simply easier as a practical legislative and law enforcement matter to keep the standard list of protected features and then to grant religious organizations a special exemption from bans on discrimination in the cases where differential treatment on religious grounds is not unjust, rather than to come up with a much more differentiated and complicated legislation against discrimination.

Both of these ways in which church autonomy is commonly thought to go beyond ordinary freedom of association are plausibly analyzed as a right consisting in certain Hohfeldian incidents: ${ }^{7}$

1 a liberty to have an internal decision-making procedure (re a) and to employ functionaries based on certain qualifications in certain job functions (re b),

2 a claim right against secular courts (re a) and employment tribunals (re b) not to interfere in or adjudicate in certain cases, and

3 an immunity from being liable to the power of secular courts or legislatures to change the normative position of religious organizations in these respects.

These incidents are sufficient to capture corporate freedom of religion as a collective form of protection. But the cases discussed by Cohen invoke an even stronger notion of church autonomy, which also involves:

4 a power of jurisdiction to change the normative situation of members of the religious organization with respect to their liberties and claims within the organization's system of rules.

The claim is not only that the state should not interfere but that religious organizations have authority to decide internal matters - and this independent jurisdiction is furthermore what is taken to justify the claim about non-interference. Some proponents of church autonomy seek to blur the distinction between protection in terms of the first three incidents and jurisdiction as a power. ${ }^{8}$ But insofar as the main focus of church autonomy is to protect religious organizations in the two noted respects in which they are especially vulnerable due to their religious nature, the liberty, claim, and immunity incidents are sufficient, and the power incident is indeed, as Cohen argues, a step beyond mere religious freedom.

\section{Grounds and subjects of rights to freedom of religion}

What might justify church autonomy in the latter jurisdictional sense identified and criticized by Cohen? Arguments for church autonomy usually start from the trivial observation that religion concerns not only individual belief and con-

7 Cf. Leif Wenar, 'Rights' in The Stanford Encyclopedia of Philosophy, ed. Edward N. Zalta (Fall 2011 Edition), <http://plato.stanford.edu/archives/fall2011/entries/rights/>.

8 Steven Douglas Smith, 'The "Jurisdictional” Conception of Church Autonomy', San Diego Legal Studies Paper No. 14-177 (2014), <http://papers.ssrn.com/sol3/papers.cfm?abstract_id= 2537024>. 
science and acts carried out by individual believers on that basis but also collective activities such as gathering for worship and associating together in religious organizations. The argument then is that, in order for religious freedom to be effective and meaningful, not only the individuals must have freedom but also the religious institutions, organizations, and groups which the individuals are members of and within which they live out their religious convictions. Hence the claim that religious organizations and institutions like churches must have rights of self-government. The claim is that the subject or holder of rights of freedom of religion is a corporate entity, namely the group or organization considered as a unitary holder of the right distinct from the individual persons who are members of the group or the organization. ${ }^{9}$ Not only individuals but also collectives or institutions should have rights of freedom of religion, because religion concerns not only individual beliefs and acts but also communal activities.

A further claim concerns the sources or grounds of this right. Rather than seeing the self-government of religious organizations as something governments bestow upon them in order, for example, to respect and protect the religious freedom of the individuals constituting the religious community in question, some proponents of church autonomy argue along the lines identified by Cohen in the American cases that

church autonomy is not by the grace of government. It is a freedom of institutions of pre-constitutional existence. It is not formed by the constitution, it has to be respected by the law. ${ }^{10}$

This view is an instance of the jurisdictional claim identified by Cohen, since selfdetermination is conceived of as being grounded in a separate source of authority outside the liberal democratic political framework, which the liberal state and constitution should respect and refrain from interfering with.

This latter claim goes further than the claim that freedom of religion is not only an individual right but also a corporate right held by institutions, organizations or groups independently from and in addition to the individual rights held by their members. We should distinguish between the sources or grounds of a right, on the one hand, and the holders or subjects of the right, on the other. The question about grounds is the one implicated in Cohen's discussion of separate jurisdictions; this is the question whether a right gets its normative authority from within and as part of the constitutional framework of the liberal state, or whether the right has sui generis grounds independent of and in potential competition with those of liberal constitutionalism.

9 Peter Jones, 'Groups and Human Rights', in Human Rights: The Hard Questions, eds. Cindy Holder and David Reidy (Cambridge: Cambridge University Press, 2013), 105.

10 Gerhard Robbers, Church Autonomy (New York: Peter Lang, 2001), 5, cited in Christoffersen, 'Church Autonomy in Nordic Law', 565. 
This distinction might resemble the one between positive law and natural law and the associated distinction between legal and natural rights. But the question here is not quite the same, since positive law is a factual and descriptive notion, claims about which can in principle be verified by empirical observations of the actual workings of a given legal system. The distinction between sources or grounds of law does not carry this legal positivist baggage, since both kinds of sources are normative sources. The distinction between freedom of religion as grounded within liberal constitutionalism and freedom of religion as having its own independent normative grounding in the independent existence of religious groups or corporations is a distinction between two normative strategies of justification.

This distinction between types of grounds of rights is different from the distinction between types of subjects of rights. In the case of the claims discussed by Cohen, the independent jurisdictional status of religious groups goes hand in hand with the conceptualization of these groups or organizations as corporate entities with an existence independent of and in addition to that of their individual members. So the idea that churches have independent corporate existence is part of the justification for why they should have rights that are not "by the grace of government', but are grounded in their own independent normative authority. But this is a contingent connection, which just happens to characterize certain justifications of church autonomy. One can hold the view that rights have normative sources outside and independent from the state, even though these rights are held by individuals - the classic notion of human rights as natural rights is a clear illustration of this possibility. And on the other hand, one can have corporate rights that get their normative justification from within a liberal constitutional system of civil law - corporate rights can be bestowed by legislatures on firms, associations and groups.

Given the difference between the questions about grounds and subjects of rights, nothing follows about the possible independent jurisdictional status of religions or religious entities from claims about whether they are corporate subjects of rights. One can argue for the claim that freedom of religion needs to include corporate rights without assuming or accepting the claim that religions constitute independent jurisdictions with independent normative authority that the liberal state has to defer to.

\section{Objects of rights to freedom of religion}

But these two cross-cutting distinctions do not exhaust the conceptual framework necessary for capturing and discussing the claims about church autonomy. A further issue also relates to the already mentioned starting point for most discussions of church autonomy, namely that religion is usually not an individual affair which people engage in as isolated solitary individuals, but a communal activity carried out within special religious institutions. 
One argument is that, because religion is practised together with others and the individual's religious life depends on the vitality of the group to which the individual belongs, 'it follows that the religious group must have some independent autonomy of its own'. ${ }^{11}$ Despite the explicit reference to group autonomy, this argument does not in itself say anything about its normative sources or the subject of the rights that are implicitly assumed by the claim that church autonomy 'follows' from the fact that religion is often communal. This suggests that what is really at stake here is a third thing, namely a question about the object of rights to freedom of religion. Rights to freedom of religion protect certain activities, most importantly the beliefs of individuals and the acts involved in manifesting and observing the requirements following from these beliefs. These activities are the objects of the protection afforded by rights to religious freedom, which can clearly be communal in nature - religious freedom for instance protects not only the right to pray but the right to worship together with other fellow believers.

But from the fact that the object of a right to religious freedom is communal it does not follow that the subject of the right is a corporate entity or that the source of the right must be traced to corporate entities existing independently from the state and having independent normative authority. ${ }^{12}$ The objects of individual rights can include communal activities - and such rights can clearly be articulated and justified within the liberal framework, as is evident from ordinary constitutional rights and human rights documents.

An additional mode of argument for church autonomy claims that 'an individual's religious freedom would be impoverished if the autonomy of the religious organizations to which he or she belongs was left unprotected'. ${ }^{13}$ This might be understood as a claim that religious freedom must include church autonomy because this is a precondition for effective individual freedom of religion.

This is an instrumental argument; church autonomy is a means to secure individual freedom of religion. As such, the argument of course depends on empirical assumptions that might be questioned. But even if we grant the necessary assumptions for the sake of argument, it still does not establish anything about the sources of religious freedom. The claim is that church autonomy is necessary to secure individual religious freedom, so what is really providing the normative justification is the individual right to freedom of religion and the concerns justifying this. Individual freedom of religion can be justified within liberal constitutionalism, so the instrumental argument does not establish or presuppose any independent religious jurisdiction as the normative source of church autonomy. And even if one thinks that the justification for individual freedom of religion derives from normative sources outside liberal constitutionalism, the argument does not establish or presuppose the existence of corporate religious entities, since the justification explicitly appeals to individual religious freedom. 
So the instrumental argument at most justifies legal corporate rights, i.e., rights with a corporate subject and communal objects, if necessary to protect individuals' religious freedom, but says nothing about the normative sources or the independent corporate existence of religious groups or institutions.

\section{The strength and scope of rights to freedom of religion}

Another argument sometimes evident in discussions of church autonomy is that, if law is only secular law, then religion is at the mercy of the state, and therefore churches must have some sort of autonomy or independent jurisdictional status. Such arguments are prompted by formulations of what secular law consists in according to which 'there are no possibilities for exceptions or changes in the law'. ${ }^{14}$

Understood as a response to this view of law, there are several problems with the argument for church autonomy. First, the conception of secular law as not admitting exemptions or accommodations is simply incorrect, both empirically (positive law often provides for exemptions) and normatively (many normative theories precisely seek to justify exemptions and accommodations within the framework of secular law and justified on secular premises).

Secondly, the argument conflates issues regarding the source of law and the extent of the protection offered by law. If the worry is that secular law will not be sufficiently accommodating of religious activities, then the immediate answer is that secular law should be changed through ordinary secular legislative procedures. Also, even though secular law might sometimes be wrong and unjust, for example if it fails to accommodate certain religious activities that should be accommodated, so can religious law - there is no guarantee that the introduction of a separate religious jurisdiction will yield better law.

A similar mistake occurs when the understandable wish of religious communities for non-interference from the state in their internal affairs is thought to be an argument for the jurisdictional claim. ${ }^{15}$ Again, the need for protection of internal affairs does not in itself require the introduction of a separate source of law internal affairs of religious organizations can be articulated as something needing protection and can receive this protection by ordinary rights of religious freedom with a communal object of protection together with ordinary rights of freedom of association within civil law.

A curious thing about many arguments for church autonomy is that, even though they often assume or claim that church autonomy requires recognition of the independent jurisdictional status of religious groups or organizations that Cohen has identified, such claims are at the same time often - at least in the European debate - explicitly limited with reference to human rights norms. An example of 
this can be found in Robbers's earlier cited case for corporate religious freedom, which is followed by this qualification:

Church autonomy means the right of self-determination of religious bodies. They decide freely about their teaching and offices, the range of their activities and the shape of their structures. They do so within the limits of the law necessary in a democratic society, and prescribed by law. Only compelling interests of the society can constitute such limits. ${ }^{16}$

The peculiar thing about this statement is that, following on the previously quoted claims about religious bodies not owing their rights of self-determination to 'the grace of government', which is reasonably interpreted as an expression of the view of religious groups as having independent jurisdictional standing, it limits religious self-determination by reference to considerations in ordinary legislation within civil law. The phrases 'necessary in a democratic society' and 'prescribed by law' refer to the limiting clauses of religious freedom in the European Convention of Human Rights, article 9(2). So Robbers's formulation situates church autonomy within a human rights framework. But the whole point of ECHR 9(2) is to allow ordinary legislative aims pursued by national governments to limit freedom of religion - which is in stark contrast to the immediately preceding claim that church autonomy is not by the grace of government.

As regards the strength of the protection offered by corporate freedom of religion, limits are here introduced which contradict the earlier articulated rationale for speaking about church autonomy in the first place, namely that religious bodies have independent jurisdictional standing that states should respect. This poses a dilemma for proponents of church autonomy: either they limit the strength and scope of the protection offered by corporate freedom of religion in order to make the claim plausible and acceptable, e.g., by invoking the well-known limitation clauses from human rights law on religious freedom, or they seek to ground church autonomy in a separate religious jurisdiction. This is a dilemma because the limits of protection invoked in the first case are needed to make it a plausible and reasonable claim, but at the same time contradict and undermine the sources of religious freedom invoked in the second case. If religious freedom were really based on a completely separate and sovereign religious jurisdiction, then rights grounded in this normative source could not admit limitations stemming from secular human rights legalization - and especially not limitations due to ordinary legislative purposes in civil law.

This is yet another reason for disaggregating corporate religious freedom and for bearing in mind that most - if not all - of the cases for church autonomy surveyed above can be accounted for without assuming the controversial claim about the sources of church autonomy in an independent religious jurisdiction that 
states should view as sovereign in its own sphere and hence as out of bounds for ordinary civil law.

\section{Conclusion}

I have analyzed a number of arguments for the jurisdictional reading of church autonomy. I have shown how these arguments run different issues together and hence how many of the concerns raised under the heading of church autonomy can be addressed without accepting the jurisdictional reading of freedom of religion. My criticisms only concern the arguments for church autonomy, which I argue do not establish the jurisdictional conclusion. This criticism does not assume that only claims that can be justified from within the liberal constitutionalist framework are in fact justified - although it is of course compatible with such views. Also, I do not imply that no claims which can only be justified by assuming an independent religious source of law are justified - rather, I have suggested that at least some of the cases thought by proponents of church autonomy to require a separate religious jurisdiction could be captured within a liberal constitutional framework. The pressing normative question concerns the extent and strength of the protection of religious organizations - especially whether they should have the kind of protection criticized by Cohen. My arguments have not addressed this important issue directly; rather, I have tried to show that some of the arguments thought by proponents of church autonomy to require such an extensive and strong protection in fact rely on problematic assumptions of equivocations. This in itself casts doubt on the Supreme Court decisions in HosannaTabor and Hobby Lobby, and rather lends support to the emerging practice of the European Court of Human Rights, which does not defer to religious authorities but both imposes procedural constraints and requires a weighing of the interests of the religious organizations against those of employees. ${ }^{17}$

17 Carolyn Evans and Anna Hood, 'Religious Autonomy and Labour Law: A Comparison of the Jurisprudence of the United States and the European Court of Human Rights', Oxford Journal of Law and Religion 1(1) (2012): 81-107. 